Revisión crítica de la causal fundante del recurso de casación en el fondo en materia civil

Alejandro Romero Seguel - Maite Aguirrezabal Grünstein - Jorge Baraona González

páginas 225-259

\title{
REVISIÓN CRÍTICA DE LA CAUSAL FUNDANTE DEL RECURSO DE CASACIÓN EN EL FONDO EN MATERIA CIVIL*
}

\author{
Alejandro Romero Seguel ${ }^{* *}$ \\ Maite Aguirrezabal Grünstein*** \\ Jorge Baraona González****
}

\begin{abstract}
RESUMEN
El presente trabajo reflexiona en torno a la causal del recurso de casación y las fuentes del Derecho, desde un punto de vista civil y procesal. En este sentido, se analiza especialmente la infracción de la ley del contrato y el sistema de casación en los principales sistemas del ordenamiento jurídico comparado. Las conclusiones giran en torno a la necesidad de ampliar el ámbito del control de la causal de casación en el sentido de qué es lo que en definitiva se controla, a través de este medio de impugnación y la propuesta de mecanismos para mejorar la labor de la Corte Suprema como garante de una aplicación del Derecho más en concordancia con el principio constitucional de la igualdad ante la ley.
\end{abstract}

* $\quad$ Este trabajo ha sido realizado dentro del Proyecto FONDECYT N ${ }^{\circ} 1060883$, "Revisión crítica de la causal fundante del recurso de casación en el fondo en materia civil”. Artículo recepcionado el 7 de abril de 2008, y aprobada su publicación el 6 de mayo de 2008.

** Alejandro Romero Seguel es abogado, doctor en Derecho por la Universidad de Navarra, profesor de Derecho Procesal, Universidad de los Andes, Director del Departamento de Derecho Procesal de la Universidad de los Andes, Vicedecano de la Facultad de Derecho de la Universidad de los Andes. Correo electrónico: aromero@ uandes.cl.

*** Maite Aguirrezabal Grünstein es doctora en Derecho por la Universidad de Navarra, profesora de Derecho procesal, Universidad de los Andes, Secretaria ejecutiva del Programa de doctorado en Derecho de la Universidad de los Andes. Correo electrónico: maguireezabal@uandes.cl.

**** Jorge Baraona González es abogado, doctor en Derecho por la Universidad de Navarra, profesor de Derecho civil, Universidad de los Andes y Universidad de Chile, Director del Departamento de Derecho Privado de la Universidad de los Andes. Correo electrónico: jbaraona@uandes.cl. 


\begin{abstract}
The present work reflects about the cassation and the sources of Law, from a civil and procedural point of view. In this sense, there is analyzed especially the infringement of the law of the contract and the system of cassation in the principal systems of the juridical compared arranging. The conclusions turn concerning the need to extend the ambience of the control of the grounds of cassation to the effect that it is what finally is controlled, across this way of contesting and the proposal of mechanisms to improve the work of the Supreme Court as guarantor of an application of the Law more in congruity with the constitutional beginning of the equality in law.
\end{abstract}

\title{
PALABRAS CLAVES
}

casación; fuente; control.

\section{KEY-WORDS}

cassation; source; control.

\section{La causal de casación y las fuentes del derecho}

\section{Presentación del tema}

Con el centenario del Código de Procedimiento Civil, acontecido el $1^{\circ}$ de marzo del año 2003, el recurso de casación en el fondo en materia civil cumplió un siglo de desempeño en nuestro ordenamiento jurídico. La incorporación de este medio de impugnación — según la historia de su establecimiento-, obedeció a razones de orden práctico. El legislador de fines del siglo XIX estimó que al introducir este instrumento, la Corte Suprema haría realidad el principio de igualdad ante la ley, a través de la unificación de la jurisprudencia ${ }^{1}$.

Como se sabe, la idea de un Tribunal de Casación parte de la base que el sistema necesita de un órgano, que erigido como Juez Supremo, garantice la certidumbre jurídica, ante el evento siempre posible de múltiples y hasta contradictorias interpretaciones judiciales; la misión de dicho órgano sería imprimir una dirección única a la interpretación de las normas jurídicas,

\footnotetext{
Sobre la incorporación del recurso de casación es de obligatoria consulta el trabajo del profesor de derecho romano y Ministro de la Corte de Apelaciones de Santiago, don Agustín Rodríguez, "Estudio sobre el recurso de casación", (Memoria premiada por la Facultad de Leyes y Ciencias Políticas de la U. de Chile), en Revista Forense Chilena, año XII, Nos. 1 y 2, pp. 5-42, y Nos. 3 y 4, pp. 129-193, 1898; COURT, Fernando G. "Nombramientos judiciales", en Revista Forense Chilena, año X, No 7, 1895, pp. 389-392; CIUDAD ESPEJO, Luciana, Origen y desarrollo de los elementos fundamentales de la casación, Santiago, Editorial Jurídica de Chile, 1965.
} 
cualquiera que fuese su rango, evitando que bajo el recurso de aplicar e interpretar se cometan errores jurídicos en la decisión de los conflictos.

En nuestra doctrina constituye una opinión común sostener que la casación en el fondo se encamina a controlar que no se desvirtúe la voluntad soberana contenida en la ley. El rol del Tribunal de Casación se reduce, exclusivamente, a un examen de la legalidad del fallo. Las voces clásicas del derecho procesal chileno han sido enfáticas ente este punto: Carlos Anabalón Sanderson, explicando en general nuestro sistema de casación afirmaba, “(...) a través de esos recursos para nada se cuenta con los hechos del pleito. Ciertamente, pues basta cerciorarse de la filosofía imperante en sus bases fundamentales para llegar al convencimiento que los recursos de casación carecen en absoluto del carácter de tercera instancia, ni siquiera de una reclamación contra una sentencia injusta, como ocurre a veces con el recurso de queja, ya que su objeto es enteramente ajeno al examen tendiente a establecer si los tribunales de una $\mathrm{u}$ otra instancia consideraron bien o mal las cuestiones de hecho del pleito, en cuya materia estos tribunales son recibidos como soberanos, y por eso son llamados los jueces del fondo"2.

Otro autor clásico, Darío Urrutia Salas, se pronunciaba en idéntica orientación, señalando que a la Corte Suprema "no le interesa la justicia o injusticia del asunto. Le interesa el respeto a la ley y precisamente su labor se concreta en mantener la exacta observación de las leyes"3.

En la doctrina a esa función a que aluden nuestros autores, por influencia de Calamandrei, se le ha denominado tradicionalmente como nomofiláctica o nomofilaxis, y consistiría en conseguir la exacta observancia de las leyes. El Tribunal de Casación tendría, en consecuencia, la misión de actuar como garante de la legalidad, velando por la recta aplicación de las denominadas normas decisorias de la litis.

El Tribunal Constitucional ha tenido la oportunidad de pronunciarse sobre nuestro sistema de casación declarando que, "mediante el recurso de casación en el fondo, el sistema procesal da eficacia al principio de legalidad y al de igualdad ante la ley. Nuestro sistema procesal constitucional contempla los siguientes principios fundamentales: jurisdicción de derecho, debido proceso y recursos procesales; la casación en el fondo es una de las máximas expresiones de la garantía del estado de derecho y de la igualdad ante la ley. La sentencia de casación en

2 ANABALÓN SANDERSON, Carlos, Tratado práctico de derecho procesal civil chileno, Santiago: Ediciones de la Universidad de Chile, 1946, t. II, p. 267.

3 URRUTIA SAlAS, Manuel, Manual de Derecho Procesal, Santiago: Editorial Jurídica de Chile, 1949, t. I, p. 237. 
Alejandro Romero Seguel

Maite Aguirrezabal Grünstein

Jorge Baraona González

el fondo que acoge el recurso pone término definitivo al conflicto con efecto de cosa juzgada y fija la doctrina generando un precedente jurisprudencial (... $)^{4}$.

Un examen de nuestra jurisprudencia en materia de casación en el fondo pone en evidencia que el fin político encargado a nuestro Tribunal de Casación, no se está cumpliendo en relación a las otras fuentes del derecho. Es un hecho objetivo que la causal legada hace más de un siglo, en la práctica está actuando como obstáculo para que se controle la juridicidad de muchas decisiones de gran relevancia. Bajo el argumento que en ellas los sentenciadores no han infringido una ley (en sentido estricto), no son sometidas al control de la Corte Suprema.

La realidad anterior, a nuestro entender, debe ser examinada por dos razones. Primero, porque el estado actual de cosas ha llevado a disminuir gradualmente la función que debe tener nuestro Tribunal de Casación en el ámbito del proceso civil. Segundo, porque se hace necesario redefinir el rol del recurso de casación en un ordenamiento jurídico que gradualmente ha ido admitiendo la utilización de otras fuentes del derecho, como fundamento de las decisiones judiciales.

No se aborda en este trabajo cuál debería ser el sistema de acceso a la casación. El tema que aquí interesa examinar es qué debe ser controlado por el Tribunal de Casación (la aplicación de la ley o la del derecho). Ahora, el hecho que en esta investigación se proponga una ampliación de la causal de la casación, para revisar la aplicación de las otras fuentes del derecho, no significa que no se tenga conciencia de la necesidad de cuantificar la capacidad real de la Corte Suprema para realizar su labor. Sin embargo este último aspecto constituye un tema que desborda el propósito de esta investigación.

\section{La causal fundante del recurso}

El artículo 940 del CPC promulgado en 1902 señalaba:

"El recurso de casación en el fondo tiene lugar contra sentencia pronunciada con infracción deley, siempreque esta infracción haya influido sustancialmente en lo dispositivo dela sentencia”.

"Sólo se concederá este recurso contra las sentencias inapelables de las Cortes de Apelaciones o de un tribunal arbitral de segunda instancia constituido por árbitros de derecho en los casos en que estos árbitros hubieran conocido de negocios de dichas Cortes".

Por su parte, el artículo 939 del CPC original indicaba las resoluciones susceptibles de este recurso disponiendo:

4 TC, $1^{\circ}$ febrero 1995, RDJ, t. 92 , sec. $6^{\text {a }}$, p. 14. 
"En general, solo se concede el recurso de casación contra las sentencias definitivas".

"Se concede contra las interlocutorias, cuando ponen término al juicio o hacen imposible su continuación”.

Dichos preceptos actualmente están refundidos en el art. 767 del CPC; allí se dispone:

"El recurso de casación en el fondo tiene lugar contra sentencias definitivas inapelables y contra sentencias interlocutorias inapelables cuando ponen término al juicio o hacen imposible su continuación, dictadas por Cortes de Apelaciones o por un tribunal arbitral de segunda instancia constituido por árbitros de derecho en los casos en que estos árbitros hayan conocido de negocios de la competencia de dichas Cortes, siempre que se hayan pronunciado con infracción de y esta haya influido substancialmente en lo dispositivo de la sentencia".

La causal fundante del recurso de casación en el fondo en materia civil constituye una proyección indiscutida de la ideología legalista que inspiró la codificación decimonónica. Como se ha explicado tantas veces por nuestra doctrina, en la visión de Andrés Bello todo reside en la ley y nada más que en la ley ${ }^{5}$.

Ratifica lo anterior Guzmán Brito, cuando puntualiza que, “el Título Preliminar del Código Civil Chileno está construido en torno a la ley. Y esto no sólo por el pensamiento de Bello, sino también por la época en que le tocó actuar: la Ley era el ideal de fuente del Derecho, no porque no se conocieran otras, sino porque no se deseaba admitir otro tipo de fuentes" ${ }^{\text {. El Mensaje }}$ del Código Civil no puede ser más clarificador del pensamiento de Bello en este tema: Yo no presumo ofreceros bajo estos respectos una obra perfecta; ninguna tal ha salido hasta ahora de las manos del hombre. Pero no temo aventurar mi juicio anunciando que por la adopción del presente proyecto se desvanecerá mucha parte de las dificultades que ahora embarazan la administración de justicia en materia civil; se cortarán en su raíz gran número de pleitos, y se granjeará tanto mayor confianza y veneración la judicatura, cuanto más patente se halle la conformidad de sus decisiones a los preceptos legales. La práctica descubrirá sin duda defectos en la ejecución de tan ardua empresa; pero la Legislatura, podrá fácilmente corregirlos con conocimiento de causa, como se ha hecho en otros países y en la misma Francia...

Cfr. FUEYO LANERI, Fernando, Interpretación y Juez, Santiago: Universidad de Chile, 1976, pp. 47-52. GUZMAN BRITO, Alejandro, "Modificaciones al título preliminar del Código Civil", (VV. AA.), en Estudios sobre reformas al Código Civil y Código de Comercio, Santiago, Editorial Jurídica de Chile, 1999, p. 42. 


\section{La infracción que justifica el recurso}

Conforme consta en la historia de la ley, a la denominada Primera Comisión se le debe la inclusión de la exigencia relativa a la entidad del agravio, expresada en la fórmula: "siempre que esta infracción haya influido sustancialmente en lo dispositivo de la sentencia"”.

El texto anterior es una variante de la casación originaria francesa, cuya causal era la violación expresa del texto de la ley ("violation expresse au texte de la loi").

Por su parte, a la Corte Suprema se le debe, durante el siglo de vigencia de este instituto, la incorporación de una serie de exigencias que han convertido al recurso de casación en un medio de impugnación extraordinario.

La primera distinción relevante en la praxis del recurso es la que separa a las normas legales en ordenatorias de la litis y en decisorias de la litis. Según la Corte Suprema, el recurso de casación en el fondo sólo puede basarse en la infracción de las que califican como decisorias de la litis $^{8}$. Esta distinción se ha justificado como una proyección de nuestro sistema de casación, que reserva al recurso de casación en la forma la observancia de las normas ordenatorias de la litis. Frente a la dificultad que surge en algunos casos para poder concretar distinción anterior, la Corte Suprema ha tenido que ir delimitando la naturaleza que se debe atribuir a un determinado tipo de normas, dentro de este dualismo normativo. Así, por ejemplo, se ha resuelto que por sí mismas no tienen el carácter de decisorias de las litis las normas relativas a la interpretación de la ley previstas entre los artículos 19 al 24 del Título preliminar del Código Civil ${ }^{9}$.

7 Cfr. TORO, David, y ECHEVERRÍA, Aníbal, Código de Procedimiento Civil Anotado, Código de Procedimiento Civil Anotado, Santiago: Imprenta Barcelona, 1902, pp. 730-731.

8 Se ha resuelto que la violación de preceptos legales que son solamente ordenatorios de la litis no puede servir de base para un recurso de casación en el fondo (CS, 16 octubre 1929, RDJ, t. 27, sec. $1^{\mathrm{a}}$ p. 571 ; CS, 10 agosto 1948, RDJ, t. 45 , sec. $1^{\text {a }}$ p. 682).

9 Se ha resuelto que la violación de los artículos 19, 20 y 22 del Código Civil no puede servir de base a un recurso de casación en el fondo, porque estas reglas sólo constituyen principios o normas generales destinados a orientar la labor de los tribunales de justicia en su función específica y primordial de averiguar y fijar el recto y genuino sentido de la ley, para aplicarla con acierto a la resolución de las controversias de que conocen, porque es requisito primordial de este recurso que la infracción invocada influya sustancialmente en lo dispositivo del fallo, condición que no puede producirse sin relacionar aquellas reglas con una ley en que propiamente descanse el fallo, es decir, que tenga el carácter de decisoria litis (CS, 11 de abril de 1955, RDJ, t. 52, sec 1a, p. 42 ; CS, 12 de mayo de 1992, RDJ, t. 89, sec. $1^{\text {a }}$ p. 51; CS, 27 de mayo 1992, RDJ, t. 89, sec. 1ª p. 55; CS, 15 de junio 1992 , RDJ, t. 89 , sec. $1^{\text {a }}$, p. 70). 
Aclarado el tipo de infracción a la legalidad que debe sustentar el recurso, en su actual desempeño la viabilidad de un recurso de casación en el fondo en materia civil está condicionada por lo menos a la observancia de catorce exigencias:

$1^{\circ}$ ) La naturaleza de la resolución recurrida, de conformidad a lo indicado en el art. 767 del $\mathrm{CPC}$;

$2^{\circ}$ El plazo para su deducción: 15 días siguientes a la fecha de la notificación de la sentencia contra la cual se recurre, salvo que sea un juicio de mínima cuantía, cuyo plazo es de 5 días (arts. 770 y $791 \mathrm{CPC}$ );

$3^{\circ}$ ) El patrocinio de abogado (art. 772);

$4^{\circ}$ El señalamiento en qué consiste el o los errores de derecho de que adolece la sentencia recurrida y el modo cómo ese o esos errores de derecho influyen sustancialmente en lo dispositivo del fallo (art. 772 CPC);

$5^{\circ}$ ) Que el recurso no adolezca de manifiesta falta de fundamentos (art. $782 \mathrm{CPC}$ ).

Estas cinco exigencias están establecidas para que el Tribunal A Quo y el Tribunal Ad Quem efectúen, según su competencia, el control de la admisibilidad del recurso. Ahora, el hecho de sortear con éxito este estudio preliminar no obsta a que la Corte Suprema desestime luego esta impugnación, declarando que no existe la infracción a la legalidad que se denunciaba por el recurrente.

A los anteriores requerimientos, que están contempladas expresamente en la ley, se deben agregar otras de directa creación jurisprudencial, a saber:

$6^{\circ}$ ) Que la norma jurídica que se denuncia como infringida califique dentro del concepto de ley. En sentido negativo, se ha resuelto que no constituye infracción de ley para los efectos del recurso de casación en el fondo: la vulneración de un Decreto Supremo; el quebrantamiento de un precepto reglamentario; la vulneración de un dictamen de la Contraloría General de la República; y la infracción de circulares administrativas ${ }^{10}$. 
$7^{\circ}$ ) La no contradicción con una doctrina jurisprudencial de la sala que conocerá del recurso, sin perjuicio que esta declaración se haga preventivamente en el estudio de admisibilidad, declarando que el recurso es inadmisible por manifiesta falta de fundamentos por esta circunstancia, conforme al art. 782 del CPC;

$8^{\circ}$ ) La debida utilización del plural a la hora de indicar el patrocinio del recurso, si se deduce conjuntamente con un recurso de casación en la forma;

$9^{\circ}$ ) Que no se invoquen subsidiaria o conjuntamente los motivos de casación;

$10^{\circ}$ ) Que las infracciones contenidas en el recurso hagan referencia a cuestiones o materias que hayan sido debatidas en el juicio;

$11^{\circ}$ ) Que las infracciones denunciadas se desarrollen con claridad y precisión, para que el Tribunal sepa la finalidad que se busca por el recurrente;

$\left.12^{\circ}\right)$ Que el recurso sea deducido por una parte del juicio;

$13^{\circ}$ ) Que no se denuncie por vía de casación en el fondo una cuestión jurídica que debió ser reclamada por la vía de la casación en la forma; y

$14^{\circ}$ ) Que el error de derecho que autoriza la invalidación del fallo guarde relación de causa a efecto con lo resolutivo de la sentencia, causando perjuicio procesal a la recurrente.

El incumplimiento u omisión de cualquiera de estas exigencias producen siempre el mismo efecto: el rechazo del recurso.

sec. $1^{\text {a }}$, p. 370 ; CS, 5 agosto de 1929 , RDJ, t. 27 , sec. $1^{\text {a }}$, p. 235 . CS, 25 de abril de 1938 , RDJ, t. 35 , sec. $1^{\text {a }}$, p. 464; CS, 4 julio de 1942 , RDJ, t. 40, sec. $1^{\text {a }}$ p. 71 ; CS, 2 de julio de 1948 , RDJ, t. 45 , sec, $1^{\text {a }}$, p. 478 ; CS, 10 noviembre de 1948, RDJ, t 46, sec 1ª, p. 851; CS, $1^{\circ}$ julio de 1954, RDJ, t. 51, sec. $1^{\text {a }}$, p. 361; CS, 7 de julio de 1954, RDJ, t. 51, sec, $1^{\text {a }}$, p. 351; CS, 14 agosto de 1956, RDJ, t. 53, sec. $1^{\text {a }}$, p. 169; CS, 4 noviembre de 1980 , RDJ, t. 77, sec. $1^{a}$ p. 114); en relación a un dictamen de la Contraloría General de la República (CS, 7 de junio de 1978, RDJ, t. 75, sec. $1^{\text {a }}$, p. 185); en la infracción de circulares administrativas (CS, 5 mayo 1983, RDJ, t. 80, sec. $1^{\text {a }}$, p. 27). Excepcionalmente se ha resuelto que la infracción de las disposiciones de un reglamento dictado por el Presidente de la República, en uso de facultades delegadas, puede ser objeto de un recurso de casación en el fondo (CS, 23 de julio 1974, RDJ, t. 71, sec. 1'a p. 113). 


\section{Tipos de infracción a la legalidad}

Ha sido la doctrina y la jurisprudencia las que han decantado las hipótesis de infracción de ley que influye en la parte dispositiva del fallo, distinguiendo las siguientes situaciones: a) la contravención formal de la ley; b) la errónea interpretación de la ley; c) la falsa aplicación de ley y, d) la infracción a las leyes reguladoras de la prueba.

Han colaborado a delimitar estas manifestaciones del agravio, entre otras, declaraciones de la Corte Suprema del siguiente tenor: las infracciones de ley pueden producirse cuando no se aplica la disposición que corresponda, cuando se aplica mal esa disposición o cuando se aplica una disposición que no corresponde ${ }^{11} ;(\ldots)$ de conformidad con lo dispuesto en el artículo 767 del Código de Procedimiento Civil, en la casación de fondo deben expresarse determinadamente las leyes infringidas ya sea porque no se aplicó la ley correspondiente o por haber aplicado una que no es la pertinente al caso o cuando se efectúa una errónea interpretación de la ley ${ }^{12}$; las normas infringidas en el fallo para que pueda prosperar un recurso de casación en el fondo, han de ser tanto las que el fallador invocó en su sentencia para resolver la cuestión controvertida, como aquellas que dejó de aplicar — normas decisoria litis-, puesto que en caso contrario esta Corte no podría dictar sentencia de reemplazo, dado el hecho que se trata de un recurso de derecho estricto ${ }^{13}$; la infracción de ley se produce cuando el juez, dentro de su libertad interpretativa, contraviene fundamentalmente su texto, cuando se da un alcance distinto del dado por el legislador, ya sea ampliando o restringiendo sus disposiciones, y, por último, cuando hace una falsa aplicación de la ley, como sucede cuando la aplica a una situación no prevista por el legislador o deja de aplicarla en el caso reglado ${ }^{14}$; para que la infracción influya en lo dispositivo del fallo es necesario que ella determine precisamente la resolución en un sentido diverso a aquel en que se hubiere pronunciado al no haberse incurrido en ella ${ }^{15}$; falsa aplicación de la ley es una violación que se da cuando aun entendiendo rectamente una norma en sí misma, se hace aplicación de ella a un hecho no regulado por la misma o se aplica de una manera de llegar a consecuencias jurídicas contrarias a las requeridas por la ley ${ }^{16}$.

La idea de una causal de casación por infracción a las leyes reguladoras de la prueba fue

objeto de debate dentro de las comisiones que discutieron el contenido que debía darse a nuestra

CS, 14 julio 1955 , RDJ, t. 52 , sec. $1^{\text {a }}$, p. 177

CS, 11 marzo 1992, RDJ, t. 89, sec. $1^{\text {a }}$, p. 24.

CS, 14 diciembre 1992, RDJ, t. 89, sec. $1^{\text {a }}$ p. 188.

CS, 5 mayo 1983, RDJ, t. 80 , sec. $1^{\text {a }}$, p. 27.

CS, 16 de enero de 1984, RDJ, t 81, sec. $1^{\text {a }}$ p. 8.

CS, 22 julio de 1992, RDJ, t. 89, sec. $1^{\text {a }}$, p. 95. 
Alejandro Romero Seguel

Maite Aguirrezabal Grünstein

Jorge Baraona González

casación. Sobre este tema, en el proyecto de ley aprobado por el Senado el 29 de diciembre de 1899 se establecía en su art. $2^{\circ}$ que el recurso de casación en el fondo, "tiene también lugar cuando la contravención consiste en admitir en la sentencia una prueba que la lei rechaza o en rechazar una prueba que la lei admite”.

En el proyecto promulgado en 1902 desapareció la mención a las leyes reguladoras de la prueba, al considerarse que esta situación estaba comprendida dentro de la hipótesis general del recurso (influencia de ley que influye en lo dispositivo del fallo) ${ }^{17}$.

Nuevamente, ha sido la jurisprudencia de la Corte Suprema la que ha tenido que ir dándole contenido a este supuesto, utilizando para ello las siguiente fórmula: "cabe entender vulneradas las normas reguladoras de la prueba, principalmente cuando los sentenciadores invierten el onus probandi, o carga de la prueba, rechazan las pruebas que la ley admite, aceptan las que la ley rechaza, desconocen el valor probatorio de las que se produjeron en el proceso cuando la ley le asigna uno determinado de carácter obligatorio o alteran la procedencia que la ley le diere"18; "las leyes reguladoras de la prueba susceptibles de casación en el fondo, son aquellas normas fundamentales impuestas por la ley a los falladores en forma ineludible, y que importan limitaciones concretas de su facultad de apreciación, dirigidas a asegurar una decisión correcta en el juzgamiento"19.

\section{El alcance del concepto de ley para efectos de la casación}

El concepto de ley contenido en el art. $1^{\circ}$ del Código Civil no ha sufrido ninguna modificación, desde su aprobación en 1855.

Cuando entró en vigencia el CPC, la concepción de ley a la que atendía la causal de casación en el fondo se limitaba a ley ordinaria y a la Constitución.

Por la evolución política que ha tenido nuestro sistema constitucional, actualmente es posible distinguir entre leyes de quórum calificado, leyes orgánicas constitucionales, tratados internacionales, decretos con fuerza de ley y, por cierto, leyes ordinarias.

17 Sobre este cambio, cfr. TORO, David, y ECHEVERRÍA, Aníbal, Código de Procedimiento Civil Anotado, ob. cit. pp. 730-731.

18 CS, 13 de julio de 2000, RDJ, t. 97, sec. $1^{\text {a }}$, p. 132; CS, 31 de julio de 2000, RDJ, t. 97, sec. $1^{\text {a }}$, p. 141. En igual sentido, entre otros, CS, 29 de enero de 1998, RDJ t. 95, sec. $1^{\text {a }}$, p. 9; CS, $1^{\circ}$ de octubre de 1998, RDJ t. 98, sec. $1^{\mathrm{a}}$, p. 167.

19 CS, 4 de enero de 2001, RDJ, t. 98 , sec. $1^{\text {a }}$, pp. 15-19. 
La diversidad de lo que hoy se entiende por ley no ha tenido incidencia en la causal de casación, salvo una situación a la que pronto nos referiremos en relación a la Constitución como norma fundante del recurso.

Tampoco ha sido un obstáculo asimilar al rango de esta fuente la figura del Decreto Ley, que es la norma jurídica que se ha producido en los quiebres institucionales que ha sufrido el país a lo largo de su historia.

En rigor, los problemas que se constatan en torno a la ley como fuente del derecho controlable por la vía del recurso de casación en el fondo provienen de otros fenómenos que pasamos a reseñar.

\subsection{La evolución institucional del derecho civil}

El panorama legislativo no se condice con la existencia de una serie de instituciones jurídicas que, sin estar reguladas en la ley, forman hoy día parte de la práctica del derecho. En el campo civil y comercial la incorporación gradual de una serie de contratos dejan al descubierto la existencia de lo que técnicamente algunos podrían calificar de una auténtica laguna legal.

Aunque la mayor parte de estas situaciones han sido colmadas a través del trabajo de la doctrina científica, se debe reconocer que esta falta de actualización genera una tensión entre la causal de casación, que como se ha dicho, está fundada en una concepción jurídica que pretendía reducir el fenómeno jurídico a lo legal. No está demás recordar que las bases fundamentales del positivismo legalista más radical son las siguientes: existe un ordenamiento jurídico compuesto por un sistema de normas, pleno, capaz de auto integración, donde el juez no tiene margen de discrecionalidad alguna, siendo un mero esclavo de la ley. La función jurisdiccional, entonces, se reduciría a aplicar la solución legal al caso concreto ${ }^{20}$.

En el campo doctrinal, para contrastar el panorama legislativo y la necesidad de una actualización institucional de nuestro derecho civil es una referencia obligada la difundida obra de Fueyo, Instituciones de Derecho Civil Moderno, publicada por la Editorial Jurídica de Chile en 1990. Ha seguido por la misma senda el trabajo de una Comisión de Reforma al Código Civil y Comercio. En esa instancia se ha generado un valioso material para enfrentar

20 Cfr. CHIAPPINI, Julio O. "La Escuela de la Exégesis en sus perfiles históricos", en Revista de Ciencias Sociales, U. de Valparaíso, № 24, 1984, p. 19. 
Alejandro Romero Seguel

Maite Aguirrezabal Grünstein

Jorge Baraona González

la reforma a los esos cuerpos legales en temas tan complejos como el sistema de fuentes del derecho hasta la incorporación de la teoría de la imprevisión y del abuso del derecho, entre otros aspectos ${ }^{21}$.

La falta de actualización legislativa que ha denunciado la doctrina tiene una consecuencia directa en relación a la causal de casación que nos ocupa. En efecto, por el simple hecho de no estar codificadas o legisladas estas instituciones en principio quedan al margen del control de casación. Como se ha dicho tantas veces, en la visión del legislador del siglo XIX la actuación del Tribunal de Casación quedó restringida a la infracción de ley. No resuelve el problema anterior el hecho que estas figuras estén desarrolladas y aceptadas por la doctrina y la jurisprudencia. Sólo si llegaran a conformar una costumbre en materia comercial tendrían la posibilidad de ser examinadas por la vía de la casación en el fondo, en cuanto se infrinjan las reglas legales que permiten darle valor a esta fuente del derecho, que sólo admite la costumbre según la ley (arts. 4 al 6 CCM y art. 2 CC).

Tal como se explicará más adelante, tampoco constituye una solución que el tema se plantee como una infracción a la denominada ley del contrato, prevista en el art. 1545 del Código Civil. La jurisprudencia en este tema ha sido vacilante y su actual tendencia ha sido profundizar en la exclusión del control de las decisiones contractuales a través de la casación en el fondo.

\subsection{La constitucionalización del derecho civil}

Uno de los fenómenos más singulares que se han producido en nuestro ordenamiento en el último tiempo, especialmente a través del aporte del recurso de protección, ha sido el fenómeno denominado como la constitucionalización del derecho civil2 ${ }^{2}$. Por ese camino se ha ido produciendo un corpus jurisprudencial que tomando como base las garantías constitucionales, ha permitido hacer el derecho civil desde la carta fundamental. No es el minuto para consignar los logros y los excesos de este camino. Lo que aquí importa es confrontar esta situación con el comportamiento del recurso de casación y su relación con la Constitución.

21 Sobre el tema cfr. los trabajos publicados con el título Estudios sobre reformas al Código Civil y Código de Comercio, Santiago, Editorial Jurídica de Chile. Un interesante aporte en TAPIA RODRÍGUEZ, Mauricio, Codigo Civil 1855-2005. Evolución y perspectivas, Santiago: Editorial Jurídica de Chile, 2005, especialmente pp. 355371.

22 Un análisis de este tema, entre otros, DOMINGUEZ AGUILA, Ramón, “Aspectos de la constitucionalización del Derecho Civil chileno", en RDJ, t. XCIII, No 3, 1996; Constitucionalización del derecho chileno, AA.VV, Universidad Austral de Chile, Santiago: Editorial Jurídica de Chile, 2003. 
El problema se ha producido puntualmente cuando la Corte Suprema ha establecido algunos parámetros restrictivos, señalando que las disposiciones de la Constitución no son denunciables por la vía del recurso de casación ${ }^{23}$.

La pauta anterior conforma claramente una regresión en la delimitación del agravio del recurso. Durante décadas la Corte Suprema no había visualizado la existencia de una dificultad técnica para controlar la recta aplicación de la Constitución en la decisión de un caso concreto. Sin pretender agotar los antecedentes, en una antigua memoria de prueba realizada en 1945 por Roberto Deik Comandari, relativa a las causales de casación en el fondo en materia civil (jurisprudencia 1933-1945), se afirmaba categóricamente: "siendo la Constitución la Ley Fundamental, demás está decir que si se infringe alguno de sus preceptos, por sentencia susceptible del Recurso de Casación en el Fondo, debe concederse este recurso extraordinario, puesto que como veremos más adelante, se admite por infracción de una ley cualquiera y con mayor razón cuando se viola una norma suprema. Cita como referencia de este criterio la sentencia publicada en la RDJ, tomo 34 página 187 (CS, 11 de enero de 1935). También las opiniones más autorizadas contradicen el planteamiento que estamos criticando. Así, por ejemplo, en el difundido Manual de Derecho Procesal de Casarino se lee: "Es evidente que dentro de la ley formal incluimos a la Constitución Política del Estado, puesto que constituye la ley suprema, y, por consiguiente, su infracción también motivará la procedencia del precitado recurso" 24 . A la misma conclusión llega Tavolari, exponiendo que, "agotada la polémica respectiva y prevaleciente la idea que la Constitución es la norma de mayor jerarquía en el ordenamiento y que ha de recibir aplicación directa, no es dudoso que, en su infracción pueda encontrarse el error de derecho que hará prosperar el recurso" 25 .

En su proyección práctica, la tesis restrictiva que se viene comentando podría llevar a generar situaciones límite. La aplicación de esta doctrina implica reconocer que la Corte Suprema ha negado el control de las decisiones judiciales en todos aquellos conflictos en que la norma decisoria de la litis sea un precepto de la carta fundamental. Naturalmente que se trata de una doctrina que pronto se debe revertir, retomando la doctrina clásica antes indicada.

\footnotetext{
23 En esta orientación, entre otras, CS, 30 de de octubre de 2002, RDJ, t. XCIX, sec. 1 a , pp. 274-279; CS., 30 de julio de 2002, rol N 3841-2001; CS, 4 de junio de 2002, rol N 873-2001; CS., 17 de abril de 2002, rol N 2843 2001. En buscador Lexis Nexis esta tendencia se aprecia en las sentencias publicadas con los siguientes números 34943, 26494, 26661, 24689, 30984, 30747, 30498, 28790, 28619, 26908, 26356, 26413, 26109, $17672,15859$. 24 CASARINO V., Mario, Manual de Derecho Procesal, Santiago: Editorial Jurídica de Chile, t. IV. 6 a ed. 2007 , p. 199. 25 TAVOLARI OLIVEROS, Raúl, Recursos de Casación y Queja, Santiago: Conosur, 1996, p. 52.
} 


\subsection{El fracaso del referimiento legislativo}

Otro elemento a considerar en relación a la infracción de ley como causal de casación en el fondo en materia civil es el rotundo fracaso que ha tenido el mecanismo incorporado en el art. $5^{\circ}$ del Código Civil.

En un completo estudio de este instrumento, Guzmán Brito señala que "Bello no dejó indicadas sus fuentes, pero debemos considerar como tales a los artículos XI y XII del Título preliminar del Código Civil del Perú (1852). El primero expresa: "La Corte Suprema está obligada a dar cuenta al Congreso, en cada legislatura, de los defectos que notare en la legislación”. El segundo dice: “Los jueces y tribunales superiores tienen la misma obligación establecida en el artículo anterior, que cumplirán por conducto de la Corte Suprema”. Bello refundió en una sola ambas disposiciones peruanas ${ }^{26}$. Según el mismo autor, el origen del "referimiento al legislador" se remonta al derecho romano postclásico, y fue perfilado por Justiniano, cuyas ideas al respecto resultaron acogidas en el Corpus iuris civilis ${ }^{27}$. Ahí aparece concebido en función de defender el monopolio del emperador para la creación del derecho por medio de leyes, para impedir que estas sean interpretadas o colmadas por los jueces, porque tal es en definitiva una manera de crear derecho extralegal. Por la consecuencia consistente en tener los jueces que ajustar su fallo a la decisión imperial, el referimiento justinianeo implicaba, además, una nítida intervención del legislador en la jurisdicción. En el caso del Código Civil de don Andrés Bello, según Guzmán Brito, el referimiento no le limita conservaba intactas sus facultades hermenéuticas en la causa singular al juez, y sólo lo dispone como un colaborador de la interpretación auténtica que está reservada solo al legislador ${ }^{28}$.

La inoperancia de este sistema puede ser certificada por cualquier juez o especialista en una determinada área del derecho privado. El poder político sólo se ha motivado a resolver temas puntuales en la inteligencia y aplicación de las normas legales, especialmente para defender el erario nacional o salvar problemas relativos al proceso penal (especialmente en materia de libertad provisional). En el campo del derecho civil, en cambio, la intervención legislativa para aclarar dudas de interpretación o salvar omisiones no ha sido la tónica, permitiendo que este tipo de situaciones se mantengan por largo tiempo. tiago: Lexis Nexis, 2007, pp. 37-38.

$27 \quad$ Idem. cit. ant.

$28 \quad$ Idem. cit. ant. p. 47 


\section{Casación y principios generales del derecho}

Una fuerte tensión entre la actual causal de casación, pensada para el control de la infracción de ley que influye en lo dispositivo del fallo, se da con las decisiones que vienen fundamentadas en los denominados principios generales del derecho.

DesdesusprimerosdíasdeactuacióncomoTribunaldeCasación,laCorteSupremasentócomo doctrinaque es improcedentelacausalque sehace consistireninfracción de principios de derecho ${ }^{29}$.

Sin embargo, la práctica judicial ha ido demostrando que la ley no es la única fuente a la que acuden los jueces para resolver un conflicto. Son cada vez más frecuentes las sentencias que vienen resolviendo o aplicando al caso concreto alguno de los principios generales del derecho, como la buena $\mathrm{fe}^{30}$, el enriquecimiento sin causa o la proscripción del abuso del derecho, entre otros.

Dicho de otra forma, aunque la ley cumple un rol fundamental dentro del sistema jurídico, es manifiesto que el Derecho no se agota exclusivamente en las normas legales, surgiendo una tensión a la hora de solicitar al Tribunal de Casación que proceda a ejercer un control acerca de la aplicación de un principio general en una determinada decisión.

Naturalmente que el problema no se da cuando la aplicación del principio general de que se trata se entienda comprendido dentro de una determinada institución jurídica reconocida por nuestro legislador. En ese caso bastará invocar la normativa legal para abrir el control casacional, salvo que el punto se dé en relación con la ley del contrato, por las restricciones que se explican con más detalle más adelante.

La dificultad en rigor surge cuando la decisión está fundamentada directamente en el principio general del derecho. En este caso, como se anticipaba la Corte Suprema ha declarado que el tema no es susceptible de denunciarse por la vía de la casación en el fondo.

Entendemos que este punto reclama una profunda revisión. Si son cada vez más frecuentes los casos donde se acude a la aplicación de los principios generales, se hace evidente que estamos frente a una realidad normativa que no se puede eludir.

29 En este sentido, CS, 14 de noviembre 1903 RDJ, t. 1, sec. $1^{\text {a }}$, p. 108; CS, 13 enero 1920, RDJ, t. 18, sec. p. 369; CS, 4 mayo 1920. R., t. 18, sec.1 a , p. 504; CS, 12 enero 1921, RDJ, t. 20, sec. $1^{\text {a }}$, p. 131; CS, 29 octubre 1949 , RDJ, t. 46 , sec. $1^{\mathrm{a}}$, p. 817.

30 Sobre este tema, CORRAL TALCIANI, Hernán, "La aplicación jurisprudencial de la buena fe objetiva en el ordenamiento civil chileno, en Cuadernos de Análisis Jurídico, (VV.AA), Santiago: Ediciones UDP, 2006, pp. $187-226$. 
Alejandro Romero Seguel

Maite Aguirrezabal Grünstein

Jorge Baraona González

Un atisbo de cambio por parte de la Corte Suprema en esta materia se advierte en algunos pronunciamientos. Así, en la histórica sentencia de fecha 9 de mayo de 2001, nuestro Máximo Tribunal procedió a validar como una auténtica norma decisoria de la litis la aplicación de una de las más típicas manifestaciones del principio general de buena, la denominada doctrina de los actos propios. Para el tema que aquí importa, la Corte Suprema le asignó a esta institución un valor normativo, admitiendo que la aplicación de esta regla es controlable a través de la casación, al declarar que aun en el caso de haber existido los errores de derecho denunciados en la casación en el fondo, ellos no han podido influir en lo dispositivo del fallo, "desde que igualmente la demanda habría de ser rechazada por aplicación de la doctrina de los actos propios..." 31 .

A ese pronunciamiento de la Corte Suprema se deben agregar otros por parte de los jueces del fondo, los que inspirados en la misma regla han procedido a rechazar una determinada acción por el solo hecho que la pretensión deducida era contraria a la doctrina de los actos propios ${ }^{32}$.

Desde el punto de vista jurídico, el solo hecho que se desestime la demanda con la invocación a esta doctrina obliga a indagar acerca del control de esta decisión por la vía de la casación en el fondo. Es evidente que este tipo de sentencias no están aplicando una norma decisoria de la litis fundada en una ley, sino que todo lo contrario, resuelven la controversia a través de los nada pacíficos principios generales del derecho ${ }^{33}$.

\section{La causal de casación y la decisión en equidad}

Tanto o más complejo que el control de las decisiones fundadas en principios generales del derecho son las fundadas en la equidad.

La dificultad aquí surge por el hecho que la equidad no evoca siempre la misma cuestión. Desde el punto de vista teórico (y en una perspectiva histórica del tema) se han distinguido tradicionalmente dos manifestaciones de la equidad, la "epieikeia" griega, como justicia individualizadora del caso concreto, y la “aequitas" romano-cristiana, como justicia igualitaria o moderadora, esto es una forma de morigerar el derecho estricto ${ }^{34}$.

31 CS, 9 de mayo de 2001, RDJ, t. 98, sec. $1^{\text {a }}$, pp. 99-100.

GJ, N²66, 2002, pp. 204-207.

Sobre el tema, BELADIEZ ROJO, Margarita, Los principios jurídicos, Madrid: Tecnos, 1997, pp. 17-42; ALCALDE RODRIGUEZ, Enrique, Los principios generales del derecho, Santiago: Ediciones Universidad Católica, 2003.

34 Como lo sintetiza Paricio, "aequitas, en el genuino sentido romano, nada tiene que ver con la epieíkeia aris- 
Por su parte, desde el punto de vista de las denominadas fuentes del derecho, la equidad se encuentra incorporada básicamente de dos formas: a) como un criterio para la interpretación o integración de las normas jurídicas, ya sea por mandato legal o bien por aplicación de algún principio general del Derecho; o, b) como un instrumento para crear el Derecho en un caso particular.

Como lo expone Falcón, "el de la equidad es un tema polifacético, una auténtica encrucijada de problemas. El estudio de la equidad se encuentra especialmente justificado desde la perspectiva filosófico-jurídica, pero no sólo desde ella. La equidad es una cuestión a investigar tanto en el ámbito de la Ciencia jurídica, como en el de la teoría de la Justicia -no olvidemos que se trata de un tipo de justicia-, en el de la Historia del Derecho -en relación con el tema de la equidad en el tiempo y el estudio dinámico de los distintos tipos históricos de equidad- o en el del Derecho Comparado -es el tratamiento de la equidad en el espacio, esto es, en los principales sistemas jurídicos de los distintos países. Destaca aquí por su importancia la cuestión de la 'equity' anglosajona" ${ }^{35}$.

Para sus detractores, la equidad es un concepto impreciso y vago, que como tal resulta peligroso. Normalmente, los que son contrarios a esta fuente del derecho ven en ella una forma de actuación jurídica que puede dar pie a la arbitrariedad o abuso de poder.

La defensa de la equidad como fuente del derecho ha contado desde antaño con un pleno reconocimiento por parte de importantes juristas y filósofos especialmente desde la perspectiva realista del derecho y de la doctrina crítica al positivismo legalista ${ }^{36}$.

En nuestro sistema de fuentes la equidad fue considerada desde los orígenes de nuestra República. La Ley Sobre el Modo de Acordar y Fundar las Sentencias, de 1851, reconoció a

totélica como correctora del derecho; sólo indicaba que era ius, y de ahí que Cicerón, Top. 2.9, pueda decir con propiedad que ius es aequitas constituta.- Cuando los juristas hablan en casos concretos (y los textos son numerosísimos) de aequm est, no se refieren a una equidad correctora del derecho, sino simplemente a lo que es el derecho en dicho caso" (PARICIO, Javier, Estudio sobre las $<<$ acciones in aequum conceptae $>>$, Milán: Giuffrè, 1986, pp. 9-10). Otros alcances del tema entre la abundante bibliografía, PRADO DONOSO, Maximiliano, "Epieikeia y razonamiento jurídico en Aristóteles", en Persona y Sociedad, vol. 17, 2003, pp. 205-225; SQUELLA NARDUCCI, Agustín, GONZALEZ, Abel, Dos concepciones de la equidad, Valparaíso: Edeval, 1981.

35 FALCÓN Y TELLA, María José, Equidad, Derecho y Justicia, Madrid: Ramón Areces, 2005, p. 28.

36 Una explicación de las concepciones filosóficas de la equidad, cfr. QUINTANA BRAVO, Fernando, Prudencia y Justicia en la aplicación del derecho, Santiago: Editorial Jurídica de Chile, 2001, pp. 130-169. 
Alejandro Romero Seguel

Maite Aguirrezabal Grünstein

Jorge Baraona González

ésta el carácter de fuente formal de general aplicación, supletoria e integradora ${ }^{37}$. La propuesta anterior fue limitada por don Andrés Bello, que admitió acudir a la "equidad natural" como regla de hermenéutica legal, para el caso excepcional que el interprete no pudiera dilucidar el sentido de la ley aplicando el método gramatical, el histórico, el teleológico y el sistemático (art. 24 CC). Con la promulgación del CPC, en 1902, se admite que, en defecto de ley, el juez pueda fundar su sentencia conforme a la equidad (art. $170 \mathrm{~N}^{\circ} 5 \mathrm{CPC}$.), rescatando el carácter integrador que tenía en la precodificación civil la equidad, esto es, como una fuente formal más para fundamentar las sentencias.

En relación al tema que aquí nos preocupa, en nuestro ordenamiento el juzgamiento conforme a la ley o la equidad constituyen dos formas de impartir justicia (de hacer el derecho) que estarían en abierta contradicción. En el terreno de los principios, y como herencia de la codificación decimonónica, se entiende que la ley tendría preeminencia en la solución de los conflictos; la equidad conformaría una fuente residual, especialmente en el caso de jueces llamados a resolver conforme a "derecho".

Avala lo anterior la existencia de un corpus jurisprudencial que ha limitado expresamente la utilización de la equidad, cuando el juez está llamado a resolver conforme a la legalidad. Dentro de las varias declaraciones, se ha sostenido que existiendo norma positiva el recurso a la equidad estaría prohibido por el ordenamiento jurídico ${ }^{38}$; "la equidad, en su faceta jurisdiccional, consiste en la cualidad del juez, sea para elaborar un principio de justicia en ausencia de ley, sea para interpretar la ley existente, adecuándola en su sentido y finalidad, del modo más justo, a la solución del caso concreto que debe resolver. Pero no lo habilita para contradecir un texto legal expreso y vigente que encarna un principio de justicia distributiva (...) "39. En idénticos términos, la CS ha resuelto, "que sólo en defecto de leyes que procedan para fundar sus resoluciones, pueden los tribunales acudir a los principios de equidad con arreglo a los cuales aquéllos deban pronunciarse..." "40; "no es aceptable aducir razones de equidad en los casos en que se formulan peticiones fundadas en la ley y en que existe ley expresa para fallar el juicio" 41 .

37 Mayores datos, cfr. TOPASIO FERRETTI, Aldo, Fuentes del Derecho Chileno en la Codificación, Valparaíso: Edeval, 1990, pp. 63 ss; GUZMÁN BRITO, Alejandro, Las reglas del "Código Civil" de chile sobre interpretación de las leyes, ob. cit., 183-206.

38 Sobre el tema, DOMINGUEZ HIDALGO, Carmen, "La equidad en la jurisprudencia”, en Interpretación, integración y razonamiento jurídico (VV. AA), Santiago: Editorial Jurídica de Chile, 1992, pp. 453-463.

39 C. de Ap. de Valparaíso, $1^{\text {o }}$ de agosto de 1979, RDJ, t. 76, sec. $5^{\text {a }}$, p. 233.

40 CS, 13 de diciembre de 1915, RDJ, t. 13, sec. $1^{\text {a }}$, p. 514.

$41 \quad \mathrm{CS}, 30$ de abril de $1942, R D J$, t. 39 , sec. $1^{\text {a }}$, pp. 554-555. 


\subsection{La decisión en equidad y la discriminación arbitraria}

¿En qué situación queda el Tribunal de Casación frente a una decisión de un juez de derecho fundada en la equidad?

Entendemos que postular la renuncia al control en casación provoca situaciones problemáticas. La mayor dificultad surge cuando a través de la utilización del principio de la inexcusabilidad y mediando la aplicación de esta fuente del derecho se ha procedido a generar una norma para un caso concreto, cuya solución pueda ser reclamada legítimamente por otros justiciables que se encuentran en un caso análogo. En tal evento, no parece razonable que a estos justiciables se les deniegue su pretensión, aduciendo, por ejemplo, que el ordenamiento jurídico no contempla tal o cual institución. Una discriminación de esta entidad, a nuestro entender, es algo que Tribunal de Casación no debería permitir, ello si quiere ser coherente con la función de garantizar la igualdad de trato jurídico que en teoría se le asigna a todo Tribunal de Casación.

En nuestra jurisprudencia ilustra con claridad el planteamiento anterior la situación surgida a raíz de uno de los pocos casos donde se ha admitido explícitamente la utilización de la equidad como norma fundante de una decisión judicial. Sin entrar en detalles, en la década de los ochenta del siglo pasado la Corte Suprema admitió una acción de retrocesión para anular la expropiación de un fundo practicada con ocasión de la denominada reforma agraria. Sin embargo, los restantes casos promovidos invocando la misma institución jurídica, y buscando el mismo fin anulatorio, la respuesta fue diversa, argumentado que nuestra legislación no contemplaba la retrocesión ${ }^{42}$.

Lo anterior se ve reforzado, por el contenido de la garantía constitucional del art. $19 \mathrm{~N}^{\circ}$ 2 de la Constitución, que proscribe la discriminación en el trato jurídico, mandato que no excepciona a los jueces.

\subsection{Los parámetros de control de las decisiones de equidad}

El hecho que las decisiones fundadas en la equidad revistan una alta complejidad, a

CS 9 de octubre de 1981, RDJ, t. 78, sec. 1a , p. 207. Sobre este tema, UGARTE GODOY, José Joaquín, "Comentarios al fallo de la Excma. Corte Suprema de fecha 19 de Noviembre de 1979, recaído en la causa Luco con Cora", y "La integración de la Ley con la Equidad y la retrocesión”, ambos artículos publicados en la RDJ, t. 76, pp. 37-50, y t. 79, pp. 31-37, respectivamente. 
Alejandro Romero Seguel

Maite Aguirrezabal Grünstein

Jorge Baraona González

nuestro entender, no debe servir de excusa para discutir acerca de la existencia de parámetros que permitan ejercer un control de estas decisiones por el Tribunal de Casación.

Como lo expone Falcón, “es característico de la equidad conceder al juez un cierto margen de libertad, un poder discrecional más o menos amplio, pero que nunca puede convertirse en un poder arbitrario. El arbitrio del juez no debe ser su capricho o una arbitrariedad que le permita basar sus decisiones en sus particulares sentimientos o en sus utópicos ideales de legislador; no es un arbitrio libre y absoluto, es un arbitrio dentro del Derecho”.

"Existen varios límites a la libertad judicial en el empleo de la equidad. Por un lado, el juzgador ha de tener en cuenta las circunstancias del caso que debe decidir, las cuales ya le marcan una cortapisa desde el punto de vista fáctico. No se trata tanto de deducir de la regla general, sino de inducir a través de la observación de los casos concretos. El empirismo pasa a un primer plano. Es preciso ponderar los intereses en juego y tener en cuenta el prototipo de conducta media adecuada para la resolución del caso"43.

La necesidad de contemplar dentro de la causal de casación la aplicación de la equidad se justifica por el amplio campo de aplicación que tiene esta fuente del derecho en la solución de los conflictos. Existe una equidad interpretativa (o infra, secundum o propter legem), una equidad supletoria o integradora (praeter o extra legem), o una equidad derogatoria o correctora de la ley (contra legem). En cada una de ellas el juzgador logra la solución para el caso concreto, ya sea interpretando una norma legal general y abstracta o bien procediendo a crear directamente la norma para caso particular, sin relación alguna con un determinado precepto que tenga su origen en un acto del Poder Legislativo (en sentido amplio).

Todo lo anterior se puede sintetizar señalando que la creación de las normas jurídicas para la decisión del los casos que se someten a la decisión no siempre se resuelve aceptando la existencia del monopolio estatal que quiere concentrar en la legalidad el sistema de producción de normas jurídicas.

En este punto es pertinente señalar algunos autores han propuesto la fijación de parámetros para controlar la decisión de equidad usando como parámetro la "legalidad". En nuestra doctrina —en relación a la figura del arbitrador - defiende esta vía Rodríguez Grez, al afirmar que, "es evidente, por otra parte, que la ley está fundada en la equidad y en valores que el legislador, al aprobarla, incorporó en ella. Al apartarse el arbitrador de la ley, así se trate de situaciones 
reguladas por normas de interés privado, confrontará su decisión con una fórmula sancionada al más alto nivel por los poderes colegisladores. En tal caso, debe en su fallo justificar esta circunstancia, consignando las razones que lo mueven a proceder de esta manera. De lo contrario infringe gravemente sus deberes. Lo que señalamos nos parece importante. La ley está fundada, como es natural, en la equidad, pero desde el punto de vista de quienes le dieron existencia y en el momento en que ella surgió a la vida jurídica. Si el arbitrador, más allá de las disposiciones de orden público, resuelve apartarse de la ley y justificar su sentencia en principios de equidad y prudencia, debe encarar la contradicción que representa contraponer dichos principios con las normas que deja de aplicar. Por lo mismo, puede el arbitrador fundar su decisión en normas jurídicas, dando por sentado que con ello expresa principios reconocidos de equidad natural. Pero puede, también, apartarse de las normas vigentes e invocar lo que le dicten su prudencia y equidad, caso en el cual está obligado a justificar su decisión y la contradicción que advierte entre las normas vigentes y los principios de equidad y prudencia que acoge en la sentencia. No nos parece correcta la posición del arbitrador que; invocando sus facultades, elude este deber, porque con ello debilita el Estado de Derecho, una de cuyas bases es la certeza de que las normas vigentes se aplicarán para resolver los conflictos jurídicos que se susciten. De lo expuesto se deduce que si el arbitrador para resolver acata la legislación vigente, se coloca automáticamente al margen de toda falta o abuso y cumple cabal y convenientemente con su deber. A la inversa, si prescinde de las normas legales en vigor, deberá justificar esta determinación para armonizar su fallo con el sistema normativo imperante"44.

Sin embargo, el planteamiento anterior podría llevar a desconocer que en una de sus manifestaciones el juicio de equidad tiene una naturaleza creadora e irrepetible, que no tiene porque guardar relación necesariamente con la legalidad vigente. Como bien lo precisa Falcón, "habría que distinguir entre el juicio legal y el juicio de equidad. El primero está en presencia de una norma legal a aplicar, que constituye un enunciando del que no se puede prescindir, que da lugar a un procedimiento silogístico. El juicio de equidad, por el contrario, se configura como un silogismo acéfalo, carente de, por así decirlo, de premisa mayor (...) en el cual la conclusión no deriva directamente de la norma jurídica, sino de consideraciones de equidad y adecuación" 45 .

Como se puede apreciar, el control de las decisiones de equidad conforma una materia singular. La actuación del Tribunal de Casación en este punto debería apuntar a la utilización

44 RODRIGUEZ GREZ, Pablo, Inexistencia y nulidad en el Código Civil chileno, Santiago: Editorial Jurídica de Chile, 1995, pp. 267-268.

45 FALCÓN Y TELLA, María José, Equidad, Derecho y Justicia, ob. cit. p. 209. 
Alejandro Romero Seguel

Maite Aguirrezabal Grünstein

Jorge Baraona González

de la técnica de control que se realiza en relación al ejercicio de facultades discrecionales de la autoridad administrativa ${ }^{46}$.

Entendemos que la circunstancia que una sentencia aplique la equidad no puede convertirse en obstáculo para su control por la vía de la casación. Nos justifica en esta apreciación la circunstancia que la jurisprudencia ha tenido que sentar pautas o criterios que dan luces sobre las infracciones que pueden resultar de la aplicación de la equidad, dejando en claro que esta forma de decidir un conflicto jurídico no es sinónimo de arbitrariedad o abuso de poder. Sintetiza muy bien este tema la sentencia de la CS, de 20 de julio de 1989, al declarar que "la decisión de la demanda intentada por Sinel en contra de ENDESA ante el árbitro, abogado don REE., ha sido expedida por un juez que, con tal carácter debe dictar su fallo obedeciendo a lo que la prudencia y equidad le aconsejaren, y como tal premisa impide enumerar factores para ello porque puede ser una enumeración incompleta, pero en todo caso no puede olvidar el arbitrador como guía los principios que informan la ley positiva, ni tampoco principios éticos como el enriquecimiento sin causa, el evitar el abuso del derecho, el aprovechamiento de la mala fe, el evitar los contratos leoninos" ${ }^{\prime 4}$.

\section{La infracción de la jurisprudencia como causal del recurso}

En la historia de la causal del recurso de casación en el fondo no prosperó la idea de incluir, junto a la infracción de la ley, la de la jurisprudencia ("doctrina legal") ${ }^{48}$. Aunque esta posibilidad venía contemplada expresamente en el proyecto de Código de Procedimiento Civil preparado por don José Bernardo Lira, en definitiva tal iniciativa no fraguó; según los comisionados con ello se confería al Poder Judicial facultades legislativas, hecho que se consideró de "enorme inconstitucionalidad"49. Conforme se lee en el Comentario al Código de

46 Sobre este tema, CORDÓN MORENO, Faustino, "El control judicial del uso por la administración de sus facultades discrecionales", en Revista de Derecho Universidad de Piura, vol N 3, 2002, pp. 157-167; ARANCIBIA MATTAR, Jaime, "Control judicial de sanciones en materia económica. Notas para una análisis del caso británico", (VV. AA), en Sanciones administraciones y derechos fundamentales: regulación y nuevo intervensionismo, Universidad Santo Tomás, 2005, pp. 155-171.

$47 \quad$ CS 20 de julio de 1989, RDJ, t. 86, sec. $1^{\text {a }}$, pp. 95-96.

48 Sobre el alcance del concepto “doctrina legal”, MUERZA ESPARZA, Julio, El motivo $1^{\circ}$ del artículo 1692 de la Ley de Enjuiciamiento Civil de 1881 y su evolución, Pamplona: Eunsa, 1986.

$49 \quad$ En la sesión $85^{\mathrm{a}}$, del 2 de mayo de 1879, la Comisión Revisora discutió este tema en los siguientes términos: "El señor Ministro propuso la supresión de la regla relativa al recurso de casación en el fondo, esto es, todo lo que en el artículo en discusión se refiere á la doctrina legal, porque nuestra legislación no dará sino en raros y determinados casos fuerza de ley á la costumbre. El señor Lira contestó que había vacilado mucho al redactar esta parte del proyecto. El ejemplo de la legislación española, posterior en esta materia á la francesa y á la belga, 
Procedimiento Civil, de Toro Melo y Echeverría, "la Primera Comisión suprimió lo relativo a la doctrina legal, porque nuestra legislación no da sino en raros y determinados casos fuerza de lei a la costumbre; i porque el recurso de casación en el fondo procura la recta interpretación de la lei, i no es lei la doctrina recibida por la jurisprudencia de los tribunales" ${ }^{50}$.

La falta de consideración a la infracción de la jurisprudencia como causal de casación en el fondo, a nuestro parecer, ha sido una de las omisiones con mayor repercusión negativa en nuestro judicial. Esta situación ha llevado a que surjan fenómenos con alta connotación negativa como es la falta de certidumbre sobre el alcance de las normas jurídicas, los cambios de criterio en la decisión sin ninguna fundamentación, y lo que es todavía peor, la discriminación de origen judicial prácticamente ilimitada que se acepta en nuestra práctica forense. En relación a este último punto, la obtención de una respuesta judicial depende de una serie de variables subjetivas. Por ejemplo, si la causa es vista en una sala $\mathrm{X}$ en una Corte de Apelaciones puede recibir una respuesta diversa de si ella es conocida en una sala $Z$; si en esa sala participa como abogado integrante el señor T no es igual que participe en la decisión el señor R, etc., etc. No exageramos al afirmar que la solución de los conflictos no parece descansar actualmente en la aplicación de un conjunto de reglas objetivas, el Derecho, sino que más bien dependen de una multiplicidad de factores subjetivos ${ }^{51}$.

así como el respeto á los principios que son la base del Derecho estricto y que el legislador puede haber dejado de consignar en la ley precisamente porque los supone universalmente reconocidos, le inclinan, por una parte, á establecer esta regla: el ejemplo de otras legislaciones, la índole de la nuestra recordada por el señor Ministro y hasta la misma confianza que su sabiduría le inspira, le llevan, por otra parte, á limitar la regla á los únicos casos de infracción de la ley; esto es, de la ley dictada por el legislador.- El señor Aldunate apoya la indicación del señor Ministro, porque no acepta los recursos de casación en el fondo sino como un medio de procurar la recta interpretación de la ley, y no es la ley la doctrina recibida por la jurisprudencia de los tribunales, á que el artículo se refiere.- Se acordó por la unanimidad suprimir la segunda parte de esta regla, es á saber, las palabras 'ó contra doctrina legal' del inciso $2 .^{\circ}$ y todo el inciso $3 .^{\circ}$ que define esta doctrina". En la propuesta original se precisaba que, "se entiende por doctrina legal (...) la que, derivada más o menos directamente de la ley, $i$ de los principios o reglas de derecho, se halla generalmente recibida por la jurisprudencia de los tribunales”.

50 TORO, David, y ECHEVERRÍA, Aníbal, Código de Procedimiento Civil Anotado, ob. cit. p. 730.

51 Esto que se describe ha sido una tónica de nuestro sistema judicial. Es ilustrativo recordar en este punto un trabajo del abogado Fernando G. Court, publicado en 1895. En relación a la incertidumbre y diversas aplicaciones de la misma ley, este autor exponía, "Si el legislador quisiera proceder á una revisión de nuestra legislación sustantiva, el Código Civil tiene aproximadamente cuarenta años de vigencia, el de Comercio treinta años y el Penal veinte; no podría ocurrir, como la fuente más autorizada de información á la jurisprudencia, que es á lo que se ocurre para estos casos en otras naciones. Las aplicaciones prácticas de las disposiciones legales hacen con mayor seguridad resaltar sus defectos ó ponen de manifiesto sus deficiencias; pero éstas es más difícil conocerlas cuando los Tribunales se constituyen en legisladores, sea aplicando la ley á casos no previstos por el legislador, sea abriendo sobre un mismo precepto legal una variedad de interpretaciones que perturban el criterio, hacen perder la fijeza y crean desconfianza en la legislación”.Por último, nuestro autor concluye con la siguiente 
Alejandro Romero Seguel

Maite Aguirrezabal Grünstein

Jorge Baraona González

Afortunadamente la situación antes descrita cuenta con los instrumentos jurídicos para que la Corte Suprema, actuando como un auténtico Tribunal de Casación pueda garantizar la certeza jurídica. El cambio de orientación en esta materia ha surgido de la reforma introducida por la Ley $\mathrm{N}^{\circ} 19.374$, de febrero de 1995. Con ella se introdujo una serie de modificaciones, que correctamente utilizadas, podrían contribuir a disminuir los excesos antes indicados y que en definitiva no son más que la falta de un encauzamiento de la jurisprudencia.

a) En primer lugar, en dicha modificación se puntualizó como requisito del recurso de casación en el fondo el señalamiento del o los errores de derecho que influyen en lo dispositivo del fallo (art. $772 \mathrm{~N}^{\circ} 1 \mathrm{CPC}$ ). Con esa referencia se ha dado un considerable margen para que se pueda fundar una casación por infracción a otro tipo de normas jurídicas, incluyendo naturalmente a la jurisprudencia de la Corte Suprema cuando ella no es respetada por las Cortes de Apelaciones. La antinomia manifiesta entre este precepto y el artículo 767 debe resolverse, a nuestro entender, considerando que la voz Derecho es más amplia que la ley.

b) Por otra parte, el artículo 782 del CPC reconoce a cada una de las salas de la Corte Suprema, en el segundo estudio de admisibilidad, la posibilidad de rechazar de inmediato el recurso de casación en el fondo, si en opinión unánime de sus integrantes adolece de una manifiesta falta de fundamentos. Lo que en principio aparece como una facultad con amplio margen de discrecionalidad, ha sido utilizada por la Corte Suprema en varias ocasiones para fortalecer el rol de la jurisprudencia en nuestro sistema de fuentes, declarando la inadmisibilidad del recurso justamente por ir contra la jurisprudencia de la Sala.

Lo anterior se ve complementado por otros instrumentos procesales, cuyo funcionamiento sólo se explican dentro de una lógica que apunta a reconocer el carácter vinculante que debe tener la jurisprudencia de nuestro Máximo Tribunal. El funcionamiento de la Corte Suprema en salas especializadas o en pleno, cuando se trata de proceder a unificar la doctrina jurisprudencial de conformidad al art. 780 del $\mathrm{CPC}^{52}$, deberían permitir que la Corte Suprema acepte revisar de un

exhortación: "Si las Cortes de Apelaciones no fijan su jurisprudencia, ni resuelven los negocios con sujeción estricta á los preceptos legales, las sentencias de primera instancia serán necesariamente descuidadas ó faltas de estudio, porque no hay estímulo para el juez, si duda que de una plumada su fallo pueda ser sustituido por otro. Muchas veces se nota que las sentencias de los jueces letrados son superiores en acierto y estudio á las de las Cortes de Apelaciones" (COURT, Fernando G. "Nombramientos judiciales", en Revista Forense Chilena, año X, $\mathrm{N}^{\circ} 7,1895$, pp. 389-391)

52 Cfr. Boletín $\mathrm{N}^{\circ}$ 858-07, Informe de la Comisión de Constitución, Legislación, Justicia y Reglamento, recaído en el proyecto de ley, en primer trámite constitucional, sobre composición, organización y atribuciones de la Corte Suprema de Justicia y modificaciones a los recursos de queja y de casación, p. 79. Otros antecedentes de este cambio, cfr. OTERO LATHROP, Miguel, Derecho Procesal Civil. Modificaciones legales 1988-2000, Santiago: 
modo preferente aquellos recursos cuya denuncia es la infracción a la doctrina jurisprudencial que emana de su potestad como Tribunal de Casación.

\section{La infracción a la denominada ley del contrato}

\subsection{Explicación previa}

Hemos dejado para el final de esta primera parte el análisis de la causal de casación más difícil de resolver, relativa al control de la denominada ley del contrato. Se trata de un punto complejo, que requiere analizar varias aristas. En este trabajo solo daremos un panorama general.

En primer lugar, el control judicial de una decisión recaída en un conflicto contractual apunta a determinar si la actuación del juez en este ámbito es una actividad en la que el juzgador se limita a dar por establecidos hechos, o si también en ella se involucra un acto de aplicación de una determinada norma jurídica.

Un contrato es la consecuencia y efecto de un acuerdo de voluntades, cuya contenido esencial es generar una o más obligaciones y que se traducen en que una parte está en la necesidad de dar, hacer o no hacer algo a favor de otra. En este sentido, un contrato es fuente de obligaciones, su contenido material es generar un lazo o vínculo entre dos personas. La descripción anterior conlleva un aspecto normativo, en cuanto impone el surgimiento de un deber de actuación exigible jurisdiccionalmente. Por ello, es explicable que el art. 1545 del Código Civil caracterice a todo contrato legalmente celebrado como una "ley para los contratantes".

Por su parte, la aplicación o etapa de cumplimiento de un contrato puede llevar a las partes a divergencias o controversias respecto de diversos aspectos: a) si ellas están o no vinculadas contractualmente; b) cuál es el tipo de vínculo, es decir que se difiera sobre la calificación jurídica del contrato; c) la existencia de una determinada obligación emanada de ese contrato; d) por último, el sentido o extensión de la obligación.

Para resolver lo anterior el Código Civil ofrece varias reglas para proceder a la interpretación de un contrato (Título XII del L. IV, arts. 1560 a 1566). Estas normas presuponen que exista un determinado contrato, pero también pueden ser servir para dar por establecido el contrato, conforme se aprecia del mandato del art. 1560. Tales mandatos no son meros consejos, puesto

Editorial Jurídica de Chile, 2000, pp. 448-452. 
Alejandro Romero Seguel

Maite Aguirrezabal Grünstein

Jorge Baraona González

que imponen al intérprete, fundamentalmente al juez, una pauta de actuación obligatoria que debe observar a la hora de resolver un conflicto de interpretación contractual ${ }^{53}$.

La primera y principal regla de interpretación de un contrato, es la que contiene el artículo 1560 del Código Civil, que dispone que "conocida claramente la intención de los contratantes debe estar a ella más que a lo literal de las palabras”.

Esta norma presupone que toda formulación lingüística tiene una proposición normativa que puede estar bien o mal recogida en las palabras que se han usado para formularla. Cada vez que el intérprete concluya, de una manera clara, que la "intención de los contratantes" es distinta a lo literal de las palabras, ha de preferir esa común intención, claramente reconocida, a la literalidad de la formulación.

Esta regla nos ayuda a comprender que todo proceso interpretativo de un contrato conlleva dos aspectos. Uno puramente material, fenomenológico, fáctico o de hecho, y uno de tipo normativo. En efecto, determinar que dos partes han celebrado un contrato, es un tema de hecho, también lo es saber en qué consiste lo que han convenido, es decir establecer cuál es el contenido material de ese contrato, determinar dónde está recogido y de qué manera. Todo esto supone una labor probatoria, cuya finalidad no es otra que asentar las bases físicas o materiales sobre las cuales se apoyará el proceso interpretativo. Por ello, el juez tendrá que conducir a las partes a probar la existencia del contrato y cuál es su contenido material: su literalidad.

Una vez que el juez tiene probado materialmente el contrato y su contenido literal, debe entrar estrictamente al proceso interpretativo, que busca fijar su alcance, esto es determinar su contenido normativo: a qué están obligadas las partes contratantes. Aquí se entra ya a una etapa normativa, pues, su finalidad es definir la extensión y ámbito de lo obligatorio, tarea que no

53 Claro Solar, Luis, Explicaciones de Derecho Civil chileno y comparado, Santiago: Nascimento, 1939, T., XII; p. 16, "la ley quiere, pues, que la voluntad de las partes sea respetada y estrictamente observada; y por lo mismo, que las convenciones sean religiosamente cumplidas. Con este fin ha dictado reglas de interpretación que el juez debe observar. No ha dejado entregada la interpretación de las convenciones a la arbitrariedad judicial; no ha dado el juez simples consejos para ilustrar su criterio en esta interpretación; sino que le ha fijado reglas que está obligado a observar y que, hallándose consignadas en preceptos legales, no pueden ser infringidas sin incurrir en una violación de ley que puede y debe ser corregida por vía de la casación". En el mismo sentido LóPEZ SANTA María, Jorge, Los Contratos, Parte general, Santiago: Editorial Jurídica de Chile, 2005, $2^{\mathrm{a}}$ ed. T. II, p. 469, “...si se viola una regla de interpretación de los contratos se viola una proposición y, por lo tanto, la norma jurídica a que ella pertenece. De lo que se desprende que es factible recurrir de casación en el fondo por haberse infringido, en la sentencia que se declaró la interpretación hecha, alguna proposición constitutiva de una regla de interpretación de los contratos". 
busca esclarecer hechos, lo que pretende es fijar las obligaciones que, conforme con el contrato, a las partes se le imponen ${ }^{54}$.

La primera regla de interpretación es aplicar el sentido literal de lo convenido, según se deduce, como disposición secundaria, del art. 1560 del Código Civil, y a contrario sensu de lo que ella explícitamente formula. Si no hay prueba clara de que hay una intención distinta a lo que formalmente se ha expresado, el contrato debe aplicarse conforme con el tenor literal que se ha probado. Por ello, el juez no debería apartarse de la literalidad del contrato a la hora de resolver controversias sobre su interpretación. Ello, sin perjuicio del resto de las reglas de interpretación complementarias, contenidas en los arts. 1561 a 1566 del Código Civil.

$\mathrm{Si}$, por el contrario, las parte han ofrecido prueba suficiente de que hay inconsistencia entre la literalidad expresada en el contrato y la común intención de los contratantes, el juez habrá de interpretar el contrato conforme con esa común intención y no debe dejarse llevar por su mera literalidad. Esta tarea tiene una dimensión fáctica, en cuanto el juez debe fijar, por los medios probatorios, cuáles es esa intención común, es decir, en qué aspecto y de qué manera se produce la divergencia entre lo querido por ellas expresado. Pero, una vez fijada claramente esa intención común, el contenido de la misma vuelve a entrar en el ámbito normativo, pues, el juez debe extender y aplicar la regla contractual a la controversia suscitada ${ }^{55}$.

Por su parte, las otras reglas contenidas en los artículos 1561 a 1566 actúan como reglas subsidiarias, en cuanto lo que buscan es precisar la regla contractual, en la perspectiva de lo que no esté resuelto por las partes de manera clara pueda ordenarse conforme con los criterios que allí se indican. Por lo mismo, son reglas obligatorias para el intérprete. Sin no son aplicadas, nos parece que hay infracción legal que puede ser controlada por la vía del recurso de casación.

54 Como lo expone López Santa María, Jorge, Los Contratos..., ob. cit, p. 523, “dentro de los tres aspectos que se distinguen en los litigios, el primero, es decir la determinación de la existencia o inexistencia de los hechos implica una cuestión de hecho. Todo lo que concierne a este primer aspecto es ajeno a la fiscalización de la Corte de casación, salvo si se hubiese incurrido en alguna vulneración de las reglas reguladoras de la prueba. En cambio, los otros dos, la calificación de los hechos y las consecuencias o efectos de ella se derivan en vistas de la aplicación de la ley, importan cuestiones de derecho, que, como tales, puede examinarse en casación".

55 Claro Solar, Luis, Explicaciones de Derecho Civil chileno y comparado, ob. cit, TXII, p. 7, "la interpretación de los contratos no se limita a veces a fijar la voluntad de las partes, sino que so pretexto de interpretarlos los jueces dan a esa voluntad una inteligencia contraria a la realidad, desconocen la intención de los contratantes, desnaturalizan las cláusulas controvertidas, y sustituyen un contrato nuevo al que las partes celebraron y que es para ellas una ley. Una interpretación semejante, sale del terreno de los simples hechos; y no puede menos de quedar sometida ala revisión y control de la Corte de Casación. La dificultad está en determinar cuando la interpretación del contrato invade el terreno del derecho y llega a violar la ley". 
Alejandro Romero Seguel

Maite Aguirrezabal Grünstein

Jorge Baraona González

\subsection{La infracción de la ley del contrato y de las leyes interpretativas. La decisión acerca si hay contrato y su calificación}

El Código ha dispuesto en el art. 1545 CC que un contrato es una ley para los contratantes $\mathrm{y}$ ha fijado reglas de interpretación. Estimamos que cada vez que un juez yerre formalmente en la aplicación de un contrato, al decidir, por ejemplo, que no hay contrato cuando sí lo hay, o cuando o se equivoque en su aplicación (interpretación), junto con estar infringiendo el contrato mismo, muchas veces estará vulnerando una ley, en el sentido formal de la palabra.

En efecto, si un juez del fondo resuelve que no hay obligación contractual, cuando sí la hay, lo que hace es desconocer el efecto obligatorio y vinculante del contrato, que para las partes tiene en virtud del artículo 1545 del Código Civil, que no puede dejar de ser aplicado. Apreciar si un hecho es un contrato o no y qué tipo de contrato es (calificarlo), no puede ser una materia que quede entregada puramente a los jueces del fondo, desde el momento que por la mala apreciación de esos hechos ha quedado sin aplicación una norma estrictamente legal. Apreciar si un determinado supuesto fáctico, que es inamovible como fenómeno, es o no un contrato, es materia que cae en el ámbito de la casación, por falta de aplicación del art. 1545 del CC.

\subsection{La interpretación propiamente tal del contrato}

La doctrina chilena tradicional no ha admitido que la interpretación del juez del fondo pueda ser alterada por la vía de la casación. Se reconoce en este punto a los jueces del fondo una potestad soberana, incluso asumiendo que se trata de una cuestión normativa. El argumento de fondo es que no hay una un ley, en el sentido formal, infringida y que si la casación tiene por finalidad controlar la aplicación de la ley, en cuanto expresión de la soberanía, la infracción de la ley del contrato, por su estrecho ámbito de aplicación (lex privata), no podría ser considerada con interés público suficiente para que la Corte Suprema controle este tipo de infracciones.

La doctrina que exponemos en el siguiente fallo resume adecuadamente lo que decimos: "que la determinación de la voluntad e intención de los contratantes, constituye un hecho de la causa que los jueces del fondo llegan a establecer en uso de sus facultades privativas y es el resultado de la valoración de las probanzas rendidas en las instancias respectivas. En cuanto tal, no es susceptible de alterarse por la vía del recurso de casación en el fondo. Por el contrario, debe mantenerse inamovible, máxime cuando ni siquiera se ha invocado una eventual vulneración de las normas reguladoras de la prueba; (...) desde el momento que el éxito del recurso quedó supeditado a que se asuma como correcta su forma de interpretación 
del contrato, significa que no puede prosperar y debe ser, entonces, desestimado "56. En este caso se discutía si una determinada cláusula, sobre cuyo contenido literal las partes no discrepaban, recogía un plazo suspensivo o extintivo, del cual dependía la vigencia de un mandato. El juez de primera instancia estimó el plazo como extintivo, pero la Corte de Apelaciones de Santiago la calificó como suspensivo. Nuestra Corte Suprema desechó el recurso, al no ser impugnable por la vía de la casación una cuestión referida únicamente a normas de interpretación de un contrato.

Creemos que la apreciación del sentido normativo de una cláusula, como seria, por ejemplo, establecer si un plazo es suspensivo o meramente extintivo, es una cuestión normativa o de derecho, puesto que no puede resolverse sino recurriendo a categorías o conceptos de Derecho $^{57}$.

La doctrina tradicional estima que la infracción de ley referida en el artículo 767 del Código de Procedimiento Civil, se refiere a una ley en el sentido formal del término. La ley del contrato no calificaría en esta disposición.

Es obvio que la norma emanada de un contrato no es estrictamente una ley, en el sentido formal del término, porque a este respecto ley sólo es aquella que constituye una producción del sistema legislativo chileno, de acuerdo con el párrafo sobre "La formación de la ley", contenido en el Capítulo V de la Constitución Política de la República, y que se estructura en tornos a los artículos 65 a 75.

Cuestión distinta es responder a la pregunta si conviene que nuestra Corte Suprema revise la aplicación que los jueces del fondo hagan de la ley (o la interpretación) de un contrato. Puede pensarse que lo que de verdad interesa es la aplicación de la ley en sentido formal, pues sólo en ella se materializa una manifestación de la soberanía popular, según se desprende de la definición del art. $1^{\circ}$ de nuestro Código Civil. La lex privata, en cambio, por su origen -una simple declaración de voluntad entre particulares-, sólo estaría destinada a regular un determinado contrato, y por lo mismo, no tendría interés para ser controlada por la vía del recurso de casación en el fondo.

\section{CS, 22 de abril de 2003, Rol 2774-2002, LexisNexis N² 27399.}

Borda, Guillermo, Tratado de Derecho Civil, Parte General, II, B. Aires: A. Perrot, $11^{\text {a }}$ ed., 1996, pp. 126-127: "resulta claro que la tarea del juez no consiste en verificar cuál ha sido la intención de las partes, sino de interpretar el significado de su declaración. No estamos, pues, en presencia de un problema de hecho, cuya existencia deba probarse; lo que hay que resolver y definir son los efectos jurídicos de la declaración. Y ésta es, típicamente una cuestión de derecho". 
Alejandro Romero Seguel

Maite Aguirrezabal Grünstein

Jorge Baraona González

Nos parece que una compresión correcta de la tarea judicial, distinguiendo por una parte el ámbito de lo fáctico de lo meramente normativo y, por otra, abandonando prejuicios ideológicos referidos a la preeminencia de la ley "pública" respecto de la ley "privada", puede ayudar a ampliar el ámbito de lo controlable por la vía de la casación, cuando esté de por medio la correcta aplicación o interpretación de un contrato.

\section{Referencias de derecho comparado}

Estimamos de utilidad dar un breve repaso a la situación de otros Tribunales de Casación, con el objeto de examinar la forma como ejercen el control de las decisiones judiciales. Tal como se apreciará, la evolución de la causal en otros ordenamientos apunta a realizar un control de la aplicación del derecho, sin restringir la actuación del órgano de casación a un examen de la legalidad en sentido estricto.

\section{El recurso de casación en el Derecho francés}

Existe unanimidad en la doctrina en cuanto a que el origen del recurso de casación, a lo menos en lo que es su concepción clásica, se encuentra en el Derecho francés ${ }^{58}$. El origen de este instituto surge como un instrumento para controlar a los jueces; el Tribunal de Casación tendría como finalidad obligar a los jueces a sujetarse estrictamente al texto de la ley. Esta opción llevó a que en su origen la casación no se concibiera como un recurso jurisdiccional; consecuente con lo anterior, el órgano de casación no tenía por función la protección de los derechos de los litigantes. El Tribunal de Casación carecía de facultades juzgadoras, limitándose sus funciones exclusivamente a verificar si existía o no una infracción de texto legal expreso.

En 1837 se reforma el sistema y el tribunal de casación se incorporó a la estructura de los órganos jurisdiccionales. Con este cambio aparece un rasgo distintivo del recurso, al que se le encomendaría fijar la unidad de la jurisprudencia para la correcta interpretación y aplicación de la ley. Al Senado-Consulto de 28 floreal del año XII, se le debe el cambio de la denominación de Tribunal de Casación por el de Corte de Casación.

En el siglo XIX, a partir de la Constitución de 1848, la Corte de Casación logra su autonomía frente al Poder Ejecutivo, manteniendo siempre como misión la de asegurar la unidad de la jurisprudencia.

58 Cfr. En este sentido Calamandrei, Piero, La casación civil, (trad, Sentís Melendo, S.), Buenos Aires: Ediar, 1945 , pp. 16 y ss. 
El conocimiento del recurso de casación en Francia ha sido entregada, como ya se señaló, a la Corte de Casación. Se trata de un tribunal de funcionamiento plural y compuesto por 160 jueces.

En cuanto a la causal fundante del recurso, el artículo 604 del Código Procesal Civil francés dispone que la finalidad del recurso se dirige a corregir la disconformidad de la sentencia recurrida en relación con el ordenamiento jurídico. Los motivos para recurrir de casación son la existencia de sentencias contradictorias, cuando sean incompatibles y ninguna sea susceptible de recurso ordinario alguno ${ }^{59}$ y cuando existan sentencias contradictorias habiéndose interpuesto sin éxito la fin de non-recevoir de cosa juzgada ante los tribunales de instancia ${ }^{60}$. También se encuentra legitimado el Fiscal de la Corte de Casación para recurrir una resolución en interés de ley $^{61}$.

\section{La casación en la nueva Ley de Enjuiciamiento Civil española}

Ha sido tradicional afirmar que la casación española no presenta los mismos rasgos que la francesa. A diferencia de esta última, que tenía fundamentos políticos, la casación hispana surge por razones jurisdiccionales y técnicas ${ }^{62}$, consagrándose como un recurso procesal extraordinario cuya competencia le corresponde al Tribunal Supremo ${ }^{63}$. Lo anterior es sin perjuicio de los recurso de casación que pueden conocer los Tribunales Superiores de Justicia de las Comunidades Autónomas ${ }^{64}$, especialmente para que "controlen la regularidad y validez de la actuación procesal desarrollada y el cumplimiento de la normativa que regula los actos y garantías procesales, anulando estas resoluciones si se han quebrantado" ${ }^{\circ 5}$.

$59 \quad$ Art. 618 del Código Procesal Civil Francés.

60 Art. 617 del Código Procesal Civil Francés.

61 Art. 618-1 del Código Procesal Civil Francés.

62 FAiren Guillén, Victor, "Recepción en España del recurso de casación francés", en Temas del ordenamiento procesal, Madrid: Tecnos, T, I, 1969, pp. 219 y ss.

63 Estas características están descritas en la LEC de 1855, que reguló por primera vez un recurso de este tipo en el ámbito civil. Cfr. En este sentido, Nieva Fenoll, Jordi, El recurso de casación civil, Barcelona: Ariel, 2003, pp. 31-32.

64 Excepcionalmente, como se ha señalado, a las Salas Civiles y Penales de los Tribunales Superiores de Justicia, cuando se trata de recursos interpuestos en contra de resoluciones de tribunales civiles con sede en alguna Comunidad Autónoma siempre que el fundamento del recurso sea la infracción de una ley civil, foral o especial propia de la Comunidad.

65 Vallespín Pérez, David, "El papel de los tribunales superiores de justicia ante la casación civil”, Justicia, 2005, p. 50 . 
Alejandro Romero Seguel

Maite Aguirrezabal Grünstein

Jorge Baraona González

La nueva Ley de Enjuiciamiento Civil española, promulgada el año 2000, introdujo un cambio sustancial en materia de casación. Dicho cuerpo legal deslinda los tradicionales motivos del recurso de casación por infracción de ley y por quebrantamiento de forma en dos recursos extraordinarios: El primero es el que da lugar al recurso de casación (arts. 477 y ss.), mientras que el segundo da lugar al recurso extraordinario por infracción procesal (arts. 468 y ss). Esta separación, se justifica en la Exposición de Motivos de la Ley cuando afirma: "Nada tiene de heterodoxo, ni orgánica ni procesalmente y menos aún, si cabe, constitucionalmente, cuando ya se han consumido dos instancias, circunscribir con rigor lógico el recurso extraordinario de casación y exigir a quien esté convencido de haberse visto perjudicado por graves infracciones procesales que no pretenda, simultáneamente, la revisión de infracciones de Derecho sustantivo. Si se está persuadido de que se ha producido una grave infracción procesal, que reclama reposición de las actuaciones al estado anterior a esa infracción, no cabe ver imposición racional en la norma que excluye pretender al mismo tiempo una nueva sentencia, en vez de tal reposición de las actuaciones. Si el recurso por infracción procesal es estimado habrá de dictarse nueva sentencia y si ésta incurriera en infracciones del Derecho material sustantivo, podrá recurrirse en casación la sentencia como en el régimen anterior a esta Ley”.

Las resoluciones susceptibles de recurrirse por infracción procesal son todas las sentencias y autos dictados por las Audiencias Provinciales que pongan fin a la segunda instancia (art. 468 en relación con el art. 466-1).

Los motivos en que debe fundarse el recurso son los siguientes (art. 469): $1^{\circ}$ ) La infracción de las normas sobre jurisdicción y competencia objetiva y funcional; $2^{\circ}$ ) La infracción de las normas procesales reguladoras de la sentencia; $3^{\circ}$ ) La infracción de las normas legales que rigen los actos y garantías del proceso cuando la infracción determine la nulidad conforme a la ley o hubiere podido producir indefensión; $4^{\circ}$ ) La vulneración, en el proceso civil, de derechos fundamentales reconocidos en el artículo 24 de la Constitución.

Junto a los motivos existe un presupuesto de admisibilidad del recurso por infracción de ley procesal y que consiste en que de ser posible, la infracción ha debido ser denunciada previamente en la primera y en segunda instancia, y caso de ser un defecto procesal subsanable, se haya pedido su subsanación (art. 469-2) ${ }^{66}$.

66 Sobre el tema, entre la abundante bibliografía, VÁzQuEz Sotelo, José Luis, "Estado Actual de la legislación procesal civil en España”, pp. 18-19; GARBerí LlobregAt, José, “Comentarios a los arts. 468 a 493 ”, en Los procesos civiles con formularios y jurisprudencia, t. 3, (dir. GARBerí Llobregat, José), Barcelona: Bosch, 2001, pp. 859 y ss; Gimeno Sendra, Vicente, "El recurso extraordinario por infracción procesal", Revista General del Derecho, 1998 (núms. 646-647), pp. 8890 y ss; Morón PALomino, Manuel, La nueva casación civil, ob. cit., págs. 68-69; 
Por regla general, el conocimiento del recurso corresponde al Tribunal Supremo.

Para el tema que aquí importa, un aspecto en el acceso a la casación española proviene de la exigencia relativa a que la sentencia recurrida presente "interés casacional" 67 . El artículo 477 de la Ley procesal civil, existirá "interés casacional": $1^{\circ}$ ) Cuando la sentencia que se recurre se oponga a la doctrina jurisprudencial del Tribunal Supremo. $2^{\circ}$ ) Cuando la sentencia que se recurre resuelva puntos y cuestiones sobre los que exista jurisprudencia contradictoria de las Audiencias Provinciales. $3^{\circ}$ ) Cuando la sentencia que se recurra aplique normas que no llevan más de cinco años en vigor, siempre que no exista doctrina jurisprudencial del Tribunal Supremo relativa a normas anteriores de igual o similar contenido.

Comosepuedeapreciarlasexigencias anterioressignificanpotenciarelroldelajurisprudencia y de la función del Tribunal Supremo español en la unificación de esta fuente del derecho.

En cuanto a los motivos del recurso, el artículo 477 establece genéricamente el siguiente: "la infracción de normas aplicables para resolver las cuestiones objeto del proceso".

\section{El recurso de casación en el proceso judicial comunitario}

En la organización jurídica de Unión Europea, se contempla la posibilidad de deducir un recurso de casación ante el Tribunal de Justicia, limitado a las cuestiones de derecho. El objeto de esta impugnación busca asegurar la unidad de interpretación del Derecho Comunitario ${ }^{68}$.

La casación comunitaria se puede interponer contra las resoluciones del tribunal de primera instancia que pongan fin al proceso, o que se pronuncien parcialmente sobre el fondo del asunto controvertido, o no se pronuncien por falta de algún presupuesto procesal. Se encuentran legitimados para interponer el recurso quienes participaron en el proceso ante el

Muñoz JimÉnez, Francisco, "Comentarios a los arts. 468 y ss”, en Comentarios a la nueva Ley de Enjuiciamiento Civil, (coord. Fernández-Ballesteros, Miguel Á., Rifá Soler, José María,Valls Gombau, José Francisco), Barcelona: Iurgium Editores/Atelier, 2000, p. 2208; NIEVA FENOLL, Jordi, El recurso de casación civil, ob. cit., pp. 38 y ss; Osorio Acosta, Ezequiel, "Comentario al art. 477 LEC", en Comentarios a la nueva Ley de Enjuiciamiento Civil, II, (dir. Lorca Navarrete, Antonio M.), Lex Nova, Valladolid, 2000, pp. 2328-2329; MUERZA ESPARZA, Julio, "Evolución del recurso de casación civil en España", en Estudios de Derecho en Homenaje a Raúl Tavolari Oliveros, (VV.AA), Santiago: LexisNexis, coord. A. Romero, 2007, pp. 238-256.

67 Sobre este tema, LOPEZ SANCHEZ, Javier, El interés casacional, Madrid: Civitas-Thomson, 2002.

68 Cfr. García-Valdecasas; FernÁNDEZ, Rafael, "El Tribunal de primera instancia de las comunidades europeas", Derecho Comunitario Europeo y su aplicación judicial (dir. Rodríguez Iglesias), Madrid: Civitas, 1993, p. 442. Nótese que utiliza el mismo criterio de la casación francesa. 
Alejandro Romero Seguel

Maite Aguirrezabal Grünstein

Jorge Baraona González

tribunal de primera instancia como partes principales o como coadyuvantes, lo que implica que el interés no presupone legitimación para interponer la casación ${ }^{69}$. También pueden impugnarse las resoluciones del tribunal de primera instancia desestimatorias de solicitudes de intervención y que pueden recurrirse dentro de las dos semanas siguientes a la fecha de la notificación, restringiéndose en este caso la legitimación para recurrir exclusivamente a la persona afectada.

En lo que respecta a los motivos de casación, ellos deben limitarse a cuestiones de Derecho $^{70}$. Los motivos de casación son: a) la incompetencia del tribunal de primera instancia; b) las irregularidades en el procedimiento de primera instancia que lesionen los intereses del recurrente o de una persona distinta del recurrente; c) violación del Derecho comunitario por el tribunal de primera instancia, "entendiendo por tal la inaplicación o la interpretación o aplicación errónea del Derecho comunitario, tanto el Derecho originario como el Derecho derivado"71.

Para recurrir es necesario que estos motivos hayan sido planteados en el proceso de primera instancia y no pueden fundarse en pruebas no presentadas oportunamente, salvo que se trate de motivos de orden público.

Por lo tanto, y como puede notarse, el Estatuto de la Unión Europea ha delimitado claramente la posibilidad de casar una resolución, estableciendo taxativamente los fundamentos que sirven de apoyo al recurso y excluyendo cualquier posibilidad de revisar los hechos.

Se ha establecido que como límite que el recurso de casación no pueda modificar el objeto del litigio planteado ante el Tribunal de Primera Instancia.

El recurso de casación podrá ser rechazado en cualquier momento por manifiestamente inadmisible o manifiestamente infundado, lo que constituye un filtro preliminar y que ha sido considerado por parte de la doctrina como una característica original del procedimiento de casación ${ }^{72}$.

69 Que en principio sólo correspondería a las partes.

70 Art. 51 del Estatuto de la Comunidad Europea. Este principio, a decir de Fuenteaja Pastor, Jesús, El Proceso Judicial Comunitario, Madrid: Marcial Pons, 1996, p. 208, presenta una doble trascendencia, ya que por una parte, sirve para aclarar que los motivos de casación no tienen por objeto restringir el control que puede ejercer el Tribunal de Justicia, y por otro lado, se exceptúa del objeto de la casación cualquier consideración sobre los hechos, que quedan definitivamente fijados por el Tribunal de Justicia de Primera Instancia.

71 Fuenteaja Pastor, Jesús, El Proceso Judicial..., op.cit., p. 209

72 Tizzano, Antonio, "Il tribunale di primo grado e la Corte di Giustizia delle Comunitta europee: le nuove regole di procedura”, Foro It., año cxvi/1991, n 12, parte iv, col. 459. 


\section{Conclusión}

Transcurrido más de un siglo de aplicación de la causal de casación en el fondo en materia civil, se hace necesario proceder a su revisión. El cambio más urgente en este punto debería orientarse a una ampliación del ámbito de la causal de casación (qué se controla por el Tribunal de Casación).

Sin perjuicio de un mayor perfeccionamiento legislativo o a través de los Autos Acordados, en la actual regulación del recurso de casación en el fondo se contienen los elementos técnicos para que la Corte Suprema pueda proceder a extender el control de la aplicación de las otras fuentes del Derecho. La antinomia que se aprecia entre el art. 772 Nos. 1 y 2 y el art. 767 del $\mathrm{CPC}$, debe ser interpretada atendiendo a la actual realidad jurídica, donde se hace patente que la decisión de los conflictos no están exclusivamente fundadas en la ley.

Entendemos que con lo anterior se potenciaría la función de la Corte Suprema, garantizando una la aplicación igualitaria del Derecho, que supere el estrecho esquema del modelo original. 